\title{
PENGARUH KONSENTRASI MALTODEKSTRIN TERHADAP KARAKTERISTIK PEPTON IKAN KAKAP (lutjanus sp.)
}

\author{
Rustina Ningsih*, Sudarno, Agustono \\ Departemen Manajemen Kesehatan Ikan-Budidaya Perairan, Fakultas Perikanan \\ dan Kelautan Universitas Airlangga, Surabaya \\ Penulis korespondensi: rustina93@yahoo.co.id
}

\begin{abstract}
Ikan kakap mengandung kadar protein 20.55\%. Protein ikan kakap yang cukup tinggi dapat dimanfaat sebagai produk hidrolisat protein seperti pepton. Pepton digunakan sebagai sumber nutrien media untuk mikroorganisme. Pepton bersifat mudah berikatan dengan air pada saat terkena udara, sehingga berpengaruh pada masa penyimpan pepton. Untuk itu, diperlukan teknik mikroenkapsulasi yang merupakan suatu teknik melapisi cairan, padatan, atau gas dengan lapisan tipis berupa material pelindung yang berfungsi dalam masa simpan. Maltodekstrin efektif untuk pelindung bahan yang dienkapsulasi dari oksidasi. Maltodekstrin memiliki kelebihan mudah larut dalam air dingin, dispersi cepat, daya larut yang tinggi. Tujuan penelitian ini untuk mengetahui pengaruh pemberian maltodekstrin terhadap karakteristik pepton ikan kakap. Produksi pepton ikan kakap menggunakan enzim papain 0,3\% dan dihidrolisis dengan suhu $60^{\circ} \mathrm{C}$ selama 5 jam, kemudian dilakukan inaktivasi enzim dan penyaringan, kemudian dilakukan pencampuran antara sampel dan maltodekstrin dengan konsentrasi 1,0\% , 2,0\%, dan 3,0\%, selanjutkan dilakukan spray drying. Penelitian ini menggunakan tiga konsentrasi berbeda dengan tiga ulangan (triplo). Hasil menunjukkan terdapat pengaruh terhadap total nitrogen, kelarutan dalam air, dan juga rendemen. Semakin besar konsentrasi maltodekstrin yang digunakan semakin rendah total nitrogen yang dihasilkan. Berdasarkan penelitian ini dapat disimpulkan dengan penambahan maltodekstrin dengan berbagai konsentrasi pada pepton ikan kakap berpengaruh terhadap kadar nitrogen, kelarutan dalam air, kadar air, dan rendemen.
\end{abstract}

Keywords: Lutjanus sp. Pepton, Hidrolisis Protein, Maltodekstrin

\section{PENDAHULUAN}

Indonesia menduduki posisi kedua dengan perikanan tangkap terbesar di dunia dengan jumlah tangkapan sebesar 6 juta ton pada tahun 2014. Sulistianto (2013) menyatakan bahwa perikanan tangkap di Indonesia mengalami peningkatan pada tahun 2006 hingga 2010 khususnya penangkapan ikan kakap. Menurut data Food and Algiculture Organization (FAO) produksi ikan kakap di Indonesia mencapai 129,7 ribu ton pada tahun 2014.

Ikan kakap mengandung kadar protein 20.55\% Jacoeb et al.,(2013). Protein ikan kakap yang cukup tinggi dapat dimanfaat sebagai produk dari hidrolisat protein seperti pepton (Nurhayati et al.,, 2013). Indonesia membutuhkan pepton dalam bidang mikrobiologi dalam jumlah banyak sehingga harus mengimpor kebutuhan pepton dengan harga yang sangat tinggi (Barokah,2014). Pepton digunakan sebagai sumber nutrien media untuk mikroorganisme (Vasquez et al., 2004). Pepton merupakan produk dari hidrolisat protein yang larut air dan tidak mengalami koagulasi jika dipanaskan (Saputra dan Hidayati, 2013). Produksi pepton dilakukan dengan cara hidrolisis secara enzimatis menggunakan enzim proteolitik. Enzim proteolitik yang digunakan dalam 
pembuatan hidrolisis protein berupa enzim papain (Alpay et al., 2015).

Pepton bersifat mudah berikatan dengan air pada saat terkena udara, sehingga berpengaruh pada masa penyimpan pepton, oleh karena itu perlu teknologi mikroenkapsulasi dalam proses pembuatan pepton. Mikroenkapsulasi merupakan suatu teknik melapisi cairan, padatan, atau gas dengan lapisan tipis berupa material pelindung yang berfungsi dalam masa simpan, Supriyadi and Sakha (2013). Ozkan and Bilek (2014) menyatakan bahwa mikroenkapsulasi adalah teknologi yang digunakan sebagai pelindung dan penstabil bahan inti. Ariestya et al., (2016) mengatakan teknologi mikroenkapsulasi untuk melindungi bahan inti dari kerusakan fisik.

Teknik mikroenkapsulasi menggunakan bahan penyalut seperti maltodekstrin, gelatin, natrium kaseinat, dan gum arab, yang paling sering digunakan yakni maltodekstrin, Batista et al., (2015). Maltodekstrin efektif untuk pelindung bahan yang dienkapsulasi dari oksidasi. Maltodekstrin memiliki kelebihan mudah larut dalam air dingin, dispersi cepat, daya larut yang tinggi, Srihari et al.,(2010). Tujuan penelitian ini untuk mengetahui pengaruh pemberian maltodekstrin terhadap karakteristik pepton ikan kakap.

\section{METODE}

\section{Alat dan Bahan}

Alat dan bahan yang di gunakan pada penelitian ini yakni mesin spray dryer Labplant SD-05. Thermostat water bath HH-6, Magnetic stirer Cimarec, Stirrer bar, pompa vakum HAHN SHIN HS-3000, corong pisah IWAKI, ikan kakap (Lutjanus sp.) dengan komposisi kadar protein $14.21 \%$, kadar air $68.01 \%$, dan $\mathrm{pH}$ 6 yang diperoleh dari pasar ikan Pabean Surabaya dengan masa penyimpanan di dalam freezer \pm 6 jam, enzim papain komersial papaya yang diperoleh dari supermarket, maltodekstrin dibeli secara online, aquadest, kertas saring Whatman No 42.

\section{Pembuatan Pepton dari Ikan Kakap (Lutjanus sp.)}

Ikan kakap (Lutjanus sp.) disiangi dan diambil dagingnya dan dihaluskan menggunakan food processor. Daging ikan kakap yang sudah halus ditimbang. Produksi pepton ikan kakap menggunakan konsentrasi enzim 0.3\%, dihidrolisis dengan suhu 60 oC selama 5 (lima) jam. Penggunaan suhu dan waktu hidrolisis mengacu pada Astuti (2014). Proses selanjutnya inaktivasi enzim menggunakan suhu $850 \mathrm{o}$ selama 15 menit. Larutan sampel disaring kemudian dilakukan pemisahan lemak menggunakan n-heksan. Cairan pepton yang diperoleh kemudian di campur dengan bahan penyalut yaitu maltodekstrin dengan konsentrasi berbeda, $1,0 \% ; 2,0 \%$; dan 3,0\% dengan perbandingan 1:3 yang mengacu pada penelitian Barokah (2014). Pepton cair dan bahan penyalut dihomogenkan kemudian dikeringkan dengan menggunakan mesin spray dryer. Bubuk pepton yang dihasilkan kemudian dilakukan pengujian kelarutan dalam air, penghitungan rendemen, dan total nitrogen

\section{Perhitungan Rendemen}

Perhitungan rendemen dihitung dari berat ikan kakap basah yang melalui proses penyaringan dan lama penyimpanan kemudian dikeringkan menjadi bubuk.

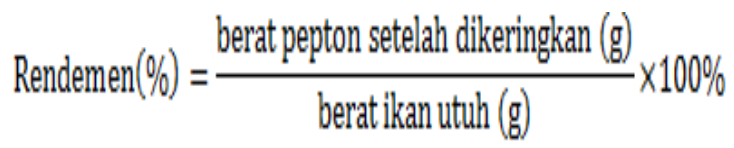

\section{Kelarutan dalam Air}

Pengujian kelarutan dalam air dilakukan dengan menggunakan metode gravimetri. Kertas saring Whatman no. 42 dikeringkan dalam oven dengan suhu $105 \mathrm{oC}$ selama 3 (tiga) jam kemudian ditimbang. Sampel sebanyak 1 (satu) g 
ditambah $150 \mathrm{ml}$ aquades kemudian disaring dengan kertas Whatman no. 42 dengan bantuan pompa vakum.

kelarutan dalam air $=\frac{100-(\mathrm{a}-\mathrm{b})}{(100-\% \mathrm{KA}) / 100) \times \mathrm{c}} \times 100 \%$

Keterangan :

$\mathrm{a}=$ kertas saring ditambah residu

$\mathrm{b}=$ kertas saring awal

$\mathrm{c}=$ berat sampel

$\mathrm{KA}=$ kadar air

\section{Perhitungan Total Nitrogen (AOAC 1995)}

Pengukuran total nitrogen dilakukan dengan metode Kjedahl. Sampel ditimbang sebanyak 0,5 g kemudian dimasukkan ke dalam labu Kjedahl $50 \mathrm{ml}$ dan ditambahkan $25 \mathrm{ml} \mathrm{H} 2 \mathrm{SO} 4$ pekat. Sampel didestruksi sampai cairan berwarna hijau bening lalu dibiarkan sampai dingin. Cairan sampel setelah dingin dipindahkan ke labu ukur dan dilakukan pengenceran dengan aquades. Sampel lalu dimasukkan ke dalam alat destilasi dan ditambahkan $10 \mathrm{ml}$ $\mathrm{NaOH}$ pekat hingga berwarna coklat kehitaman, kemudian didestilasi. Hasil destilasi ditampung dalam Erlenmeyer berisi $125 \mathrm{ml} \mathrm{H} 3 \mathrm{BO} 3$, lalu ditritasi dengan $\mathrm{HCl} 0,02 \mathrm{~N}$. Larutan blanko dianilisis seperti sampel. Perhitungan total nitrogen dengan rumus:

$$
\mathrm{N}(\%)=\frac{(\mathrm{ml} \text { sampel }-\mathrm{ml} \mathrm{HCl} \text { blanko }) \times \mathrm{N} \mathrm{HCl} \times 14,007 \times 100 \%}{\text { berat sampel }(\mathrm{mg})}
$$

$\%$ Protein $=\% \mathrm{~N} \times 6.25$

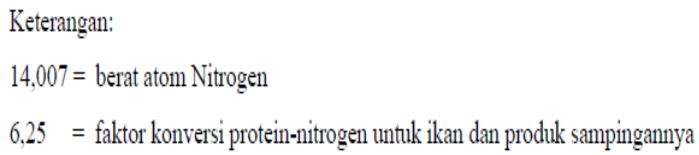

\section{HASIL DAN PEMBAHASAN}

Pepton ikan kakap (Lutjanus sp.) dikarakterisasi setelah diberikan tiga perlakuan dengan konsentrasi maltodekstrin yang berbeda. Karakteristik dilakukan dengan empat parameter yaitu total nitrogen, kelarutan dalam air, rendemen, dan $\mathrm{pH}$. Hasil dari karakteristik pepton ikan kakap karakteristik pepton ikan kakap dapat dilihat pada Tabel 1.

Bahan baku ikan kakap memiliki kadar protein sebesar $14.21 \%$, Jacoeb et al. (2013) mengatakan bahwa kadar protein ikan kakap sebesar $20.55 \%$, perbedaan komposisi kimia ikan dapat dipengaruh oleh beberapa faktor, seperti lingkungan, spesies, habitat, umur, ketersediaan pakan dalam habitat dan juga kualitas pakan. Kualitas pakan ikan juga tergantung jumlah ketersediaan zat makanan yang digunakan dalam pakan, untuk mengetahui kualitas pakan ikan yang dapat dicerna yaitu dengan cara mengukur efisiensi pakan bagi tubuh ikan adalah melalui kecernaan (Agustono, 2014).

Tabel 1. Perbandingan Karakteristik Pepton Ikan Kakap (Lutjanus sp.) dengan pepton mikroenkapsulasi dan pepton komersial oxoid

\begin{tabular}{|c|c|c|c|c|c|}
\hline \multirow[t]{2}{*}{ Parameter } & \multicolumn{3}{|c|}{ Konsentrasi } & \multirow{2}{*}{$\begin{array}{l}\text { Pepton } \\
\text { Mikroenkapsulasi } \\
\text { (1) }\end{array}$} & \multirow{2}{*}{$\begin{array}{l}\text { pepton } \\
\text { Oxoid } \\
\text { (2) }\end{array}$} \\
\hline & $\begin{array}{l}1,0 \% \\
(\mathrm{w} / \mathrm{v})\end{array}$ & $2,0 \%(w / v)$ & $3,0 \%(\mathrm{w} / \mathrm{v})$ & & \\
\hline $\begin{array}{l}\text { Kadar Protein } \\
(\%)\end{array}$ & $\begin{array}{r}38,31 \pm \\
0,76\end{array}$ & $\begin{array}{r}26,75 \pm \\
0,35\end{array}$ & $\begin{array}{r}20,41 \pm \\
0,12\end{array}$ & 67,29 & - \\
\hline $\begin{array}{l}\text { Total Nitrogen } \\
(\%)\end{array}$ & $\begin{array}{r}6,13 \pm \\
0,12\end{array}$ & $\begin{array}{r}4,28 \pm \\
0,05\end{array}$ & $\begin{array}{r}3,26 \pm \\
0,01\end{array}$ & 10,05 & 13,90 \\
\hline
\end{tabular}




\begin{tabular}{lrrrrr}
\hline Kelarutan (\%) & $95,33 \pm$ & $96,45 \pm$ & $95,03 \pm$ & 98,87 & 99,00 \\
& 1,68 & 1,25 & 1,62 & & \\
Kadar Air (\%) & $7,99 \pm$ & $6,55 \pm$ & $6,76 \pm$ & 6,28 & - \\
& 0,65 & 0,44 & 0,60 & & \\
Rendemen (\%) & 2,04 & 2,5 & 1,2 & 16,6 & - \\
\hline
\end{tabular}

Kadar protein bahan baku mempengaruhi total nitrogen pepton ikan kakap (Diniz et al., 1997). Laoli (2015) menyatakan semakin tinggi kadar protein bahan baku yang digunakan, maka semakin besar pula nitrogen yang dihasilkan, karena nitrogen merupakan unsur dari protein. Total nitrogen pepton ikan kakap lebih rendah daripada pepton komersil dan juga pepton mikroenkapsulasi. Hal tersebut di duga karena proses hidrolisis kurang sempurna. Total nitrogen didapatkan dari hasil pemecahan ikatan peptida menjadi peptida sederhana dan asam amino selama proses hidrolisis (Noman et al., 2018). Hidrolisis protein dipengaruhi oleh beberapa faktor yaitu, suhu, waktu, pH, dan konsentrasi enzim (Chalamaiah et al., 2012).Total nitrogen menurun seiring penambahan maltodekstrin, semakin besar konsentrasi maltodekstrin yang digunakan semakin rendah total nitrogen yang dihasilkan. Total nitrogen terbaik terdapat pada konsentrasi maltodekstrin $1,0 \%$ namun belum memenuhi kualiatas pepton komersial.

Kelarutan pepton ikan kakap cukup tinggi, perhitungan kelarutan pepton dalam air menggunakan metode gravimetri yang mengacu pada Fardiaz et al. (1992). Yuliawaty et al. (2015) menyatakan kelarutan tinggi disebabkan gugus hidroksil yang terdapat dalam maltodekstrin berinteraksi dengan air, keberadaan gugus-gugus bermuatan banyak pada asam amino, akan menyebabkan gugus-gugus ini dapat larut dalam pelarut polar seperti air dan metanol (Rodwell et al., 1985). Selain ini dengan penambahan maltodekstrin yang memiliki berat molekut kecil dan struktur yang sederhana dan dapat berinteraksi dengan air. Finotelli et al. (2009) menyatakan bahwa semakin kecil ukuran mikroenkapsulat maka distribusi partikel akan semakin homogen. Kelarutan pepton ikan kakap dalam air cukup tinggi. Menurut Benjakul dan Morissey (1997) proses hidrolisis menggunakan enzim dapat meningkatkan kelarutan protein. Nurhayati et al. (2013) menyatakan semakin tinggi kelarutan pepton dalam air maka semakin baik, karena kalarutan pepton menentukan kualitas produk pepton.

Kadar air pepton ikan kakap dengan pemberian maltodekstrin 3,0 \% hampir sama dengan kadar air pepton mikroenkapsulasi, hal ini karena penambahan maltodekstrin yang memiliki berat molekul kecil serta struktur yang sederhana, sehingga pada saat proses pengeringan menggunakan mesin spray dryer dapat menguap dengan mudah. Kandungan air dalam pepton ikan kakap dapat menentukan masa simpan pepton, semakin rendah kadar air maka semakin lama masa penyimpanan pepton.

Rendemen merupakan perbandingan antara bahan baku yang digunakan dengan produk yang dihasilkan (Liang, 2009). Rendemen pepton ikan kakap lebih rendah dibandingkan pepton mikroenkapsulasi yang mengacu Barokah (2014), hal ini dipengaruhi oleh komposisi bahan baku yang digunakan dalam proses pembuatan pepton. Kadar air yang rendah pada produk pepton karena kandungan air dalam substrat digunakan untuk memecah protein 
menjadi asam-asam amino pada saat hidrolisis.

\section{KESIMPULAN}

Berdasarkan penelitian ini dapat disimpulkan dengan penambahan maltodekstrin dengan berbagai konsentrasi pada pepton ikan kakap berpengaruh terhadap kadar nitrogen, kelarutan dalam air, kadar air,dan rendemen.

\section{DAFTAR PUSTAKA}

Agustono. 2014. Pengukuran Kecernaan Protein Kasar, Serat Kasar, Lemak Kasar, Betn, dan Energi pada Pakan Komersial Ikan Gurami (Osphronemus gouramy) denfan Menggunakan Teknik Pembedahan. Jurnal Ilmiah Perikanan dan Kelautan 6(1).

Alpay, P. and Uygun, D. A.. 2015. Usage of Immobilized Papain for Enzymatic Hydrolysis of Proteins. Journal of Molecular Catalysis and Enzymatic 111: 56-63.

Ariestya. D. I., Swastawati, F., Susanto, E.. 2016. Antimicrobial Activity of Microencapsulation Liquid Smoke on Tilapia[Oreochromis niloticus (Linnaeus, 1758)] Meat for Preservatives in Cold Storage $( \pm$ $\left.5^{\circ} \mathrm{C}\right)$. Aquatic Procedia (7):19-27.

Astuti, E. R. 2014. Aplikasi Pepton Berbahan Baku Ikan Hasil Tangkap Sampingan (HTS) Busuk sebagai Komponen Media Pertumbuhan Bakteri dan Khamir [Skripsi]. Fakultas Perikanan dan Ilmu Kelautan. Institut Pertanian Bogor. Bogor. $19 \mathrm{Hal}$

Barokah, G. R. 2014. Karakteristik Mikroenkapsulat Pepton Berbahan Dasar Ikan Hasil Tangkapan Sampingan (HTS) Multispesies Busuk dengan Metode Spray Drying dan Bahan Penyalut Maltodekstrin [Skripsi]. Fakultas Perikanan dan
Ilmu Kelautan. Institut Pertanian Bogor. Bogor. $29 \mathrm{Hal}$

Batista, C. A., Constenla, D., RamirezRigo, M. V., Pina, J. 2015. The Use of Arabic Gum, Maltodextrin and Surfactans in the Microencapsulation of Phytosterols by Spray Drying. Journal of Powder Technology 286:193-201.

Morrissey, B. S. 1997. Protein Hydrolysates from Pacific Whiting Solid Wastes. Journal of Agricultural and Food Chemistry 45:3423-3430.

Chalamaiah, M. R., Hemalatha, T., Jyothirmayi. 2012 Fish protein hydrolysates: proximate

composition amino acid composition, antioxidant activities and applications: a review. Food Chemistry 135 (4): 3020-3038.

Diniz, F. M, and Martin, A.M.. 1997. Optimization of nitrogen recovery in the enzymatic hydrolysis of dogfish (Squalus acanthias) protein. Composition of the hydrolysates. International Journal of Food Science and Nutrititon 48 (3): 191200.

Finotelli, G., Rosenberg, M., Kopelman, I.J., Talmon, Y. 2009. Factors affecting retention in spray drying microencapsulation of volatile materials. Journal

Agriculture Food Chemistry 38: 12881294

Jacoeb. A. M., Nurjanah, Saraswati, A. 2013. Kandungan Asam Lemak dan Kolesterol Kakap Merah (Lutjanus bohar) Setelah Pengukusan. JPHPI 2013. 16 (2)

KKP. 2014. Kelautan dan Perikanan Dalam Angka 2014

Laoli, B., Sukirno dan Edison. 2013. Ekstraksi Pepton Dari Limbah Pengolahan Ikan Cunang (Congresox talabon) Sebagai Nutrisi Pada Medium Pertumbuhan Mikroorganisme. Fakultas Perikanan 
dan ilmu kelautan Universitas Riau. Riau. 12 hal.

Noman,A.,Y., Xu, W.Q., AL-Bukhaiti, Sherif, M. A., Abdelmoneim, H. A., Abubakar, H. R, W, Xia. 2018. Influence of enzymatic hydrolysis conditions on the degree of hydrolysis and functional properties of protein hydrolysate obtained from Chinese sturgeon

(Acipenser sinensis) by using papain enzyme. Process Biochemistry: 1359-5113

Nurhayati, T., Desniar, S. Made. 2013. Pembuatan Pepton Secara Enzimatis Menggunakan Bahan Baku Jeroan Ikan Tongkol. JPHPI. 16 (1).

Ozkan, G. and S. E. Bilek. 2014. Microencapsulation of Natural Food Colourants. International Journal of Nutrition and Food Sciences 3(3): 145-156

Rodwell, V. W., Peter, A. M., Daryl, K., David, M. V. 1985. Harper's Review of Biochemistry. Ed ke-20. Darmawan I, penerjemah. Jakarta: EGC. Penerbit Buku Kedokteran. Terjemahan dari: Harper's Review of Biochemistry.

Saputra. D dan T. Nurhayati. 2013. Produksi dan Aplikasi Pepton Ikan Selar Untuk Media Pertumbuhan Bakteri. JPHPI 16 (3).
Srihari, E., Lingganingrum, F. S., Hervita, R., Wijaya, S. 2010. Pengaruh Penambahan Maltodekstrin pada Pembuatan Santan Kelapa Bubuk. Seminar Rekayasa Kimia dan Proses: 1411-4216.

Sulistianto,.E. 2013. Analisis Bioekonomi Pemanfaatan Sumberdaya Ikan Kakap di Kabupaten Kutai Timur. Jurnal Ilmu Perikanan Tropis 18 (2).

Supriyadi, A., Shakha, R., 2013. Characterictic of Microcapsules Volatile Oil Lengkuas with Maltodextrin as encapsulated. Jurnal Teknologi dan Industri Pangan 24(2): 201-208.

Vasquez, J. A., Gonzalez, M.P., Murado, M.A. 2004. A New Marine Medium Use of Different Fish Peptones and Comparative Study of the Growth of Selected Species of Marine Bacteria. Journal of Enzyme and Microbial Technology 35: 385-392

Yuliawaty. S.T., dan Susanto, W. H.. 2015. Pengaruh Lama Pengeringan dan Konsentrasi Maltodekstrin Terhadap Karakterisktik Fisik Kimia dan Organoleptik Minuman Instan daun Mengkudu (Morinda citrifolia L). Jurnal Pangan dan Agroindustri 3(1): 41-52. 